\title{
9
}

\section{Diasporic Shrines: Transnational Networks Linking South Asia through Pilgrimage and Welfare Development}

\author{
Virinder S Kalra, Umber Ibad and Navtej K Purewal
}

\section{Introduction}

The majority of the literature on diaspora has hitherto focused largely on flows, nodes and places that privilege links between the 'West and the rest' (Hall 1992). In a more subtle manner, this lens refers to networks of metropolitan cities and peripheral sites. Connections between Southall and Jalandhar may be a case in point, or Bradford and Mirpur, or New Jersey and Gujranwala, connected through people, commodities and institutions to form a 'diasporic space' (Brah 1996). However, there are various cases where the idea of diaspora does not include the West, constituted by places that are connected across a divided region. One such context is that of India and Pakistan. The formation of these two nation states was accompanied by mass migration, mostly forced, but also some voluntary (Kaur 2007). It resulted over a period of time in a hardening of the border around the time of the 1965 Indo-Pak war and thereafter which mostly sealed the national territorial boundaries, making it difficult to move across for ordinary citizens (Purewal 2006). The inability to travel across the border has created a distinct, if small amount of creative outpouring in the field of literature, film and music, firstly lamenting the violence that created the border, but also the subsequent loss of contact between co-habitants. For Punjabis this fell along the lines of religion, with Punjabi Muslims effectively cut off from Hindus and Sikhs and vice-versa. ${ }^{1}$ In a sense, this parallels the exile of Palestinians from their homelands, as those living in Jordan, Lebanon 


\section{PROOF}

Virinder S. Kalra et al. 177

or Syria who are in a similar linguistic and cultural paradigm but do not necessarily feel they belong within those nation states. ${ }^{2}$ Purewal notes how those who moved across both sides of the Punjab border were always rendered as outsiders and have, in various ways, had to negotiate this in their subsequent settlements. Similar to other diasporic contexts there is little doubt that any opening of the border between India and Pakistan would not result in a mass return movement of people, just as there is little indication that large numbers of South Asians intend to return from Canada or Europe. But this does not mean that there is no desire to cross the border, to visit the village or family home, or to see those streets that are described and passed on through oral history. It is the restriction, the inability to visit, that heightens the sense of loss and desire for return.

It is useful to view the Punjabi diaspora in particular in this way because of the co-incidence with other transnational travels that mark this community in the colonial and postcolonial era. Those in Malaysia and Singapore in 1947 found themselves without home and country as the line that split India and Pakistan rendered villages, people and histories asunder. If we think of the Punjabi diaspora in the context of India and Pakistan, then what work is enabled by adopting this conceptual framework. At its most base level it alerts us to the activities and desires of groups of people rather than the machinations of the two states and their history of antagonisms and rapprochement (Talbot 2000; Oldenburg 2010). In turn the desire of those sitting in Amritsar to visit Lahore, a distance of only $60 \mathrm{~km}$ mirrors those who are in exile and cannot visit or return, those persecuted and those otherwise barred. The more specific literature on diaspora, religion and development also needs to be adapted and moulded to provide insight into this situation. Perhaps it is useful to distinguish between what might be called the metropolitan Punjabi diaspora and that which is divided between East and West Punjab. At least at the level of access, being in the metropolitan Punjabi diaspora facilitates communication and travel across the Indo-Pak border. The cost of a phone call between Amritsar and Lahore is about Rs 25 per minute, whereas the cost of a call from the United Kingdom to Amritsar is only Rs 1.5 per minute and to Lahore about Rs 3 per minute. A European or North American passport enables a circumvention of the barriers erected by the visa regime directed towards making it almost impossible for Indians and Pakistanis to cross by land at the Wagah border (Kalra and Purewal 1999). Internet technologies open up the possibilities of communication but are accessible via forums and in the language of the metropole. Encounters and 
interactions between Indians and Pakistanis, East and West Punjabis are more frequent and more likely in Southall, Vancouver and Berlin than in Lahore, Amritsar, Delhi or Islamabad. Nonetheless, it could be argued that the role of those engaged in transnational links across the Indo-Pak border are engaged in a type of Track III people-to-people diplomacy that has greater longer term implications than the more frequent interactions in metropolitan diaspora spaces. One mechanism by which this facilitation takes place is through the pilgrimage to religious sites and shrines across the border.

After the partition of land and people in 1947, subsequently the division of many other things took place between India and Pakistan. The Punjab University in Lahore spawned a twin, first located in Simla, then with a final home in Chandigarh. The books of the University library were split and divided. Similarly, the collection of works in the Lahore Museum was divided and spread over a few museums in East Punjab. However, what could not be divided were those fixed sites of religious significance to various congregations. The birthplace of Guru Nanak, the Katas Raj Temple and the Gorak Nath Dera were all left in Pakistan, while innumerable Sufi shrines, such as Roza Shareef, were left in India. These could not be split or lifted or recreated. To fulfil the desire of pilgrims to visit, a special visa regime for Pilgrims was established in the early 1990s. At the time of Diwali, Vaisakhi and Guru Nanak's birthday, group visas would be issued to organized pilgrim parties. Over time these pilgrims would be the main source of interaction between former co-habitants and thus their significance as a source of people-to-people contact became more important. The next section will explore how this movement might be conceptualized in the existing literature on diaspora.

\section{Diaspora, religion and development}

As diasporas form and cohere, it is necessary that the question of nationalism and belonging come into tension. For some, this results in the creation of formations that celebrate the past in the present, or the 'there and here' through the creation of hybrid identities such as BritishIndian and Punjabi-Canadian. In East Punjab this is seen in shop fronts with the name Lyallpur Clothes Shop, or Lahore Band Baja; similarly, in West Punjab the Jalandhari and Ludhianvi remain epithets to people's names and naming that refers to that which was left behind and exists on the 'other side'. However, a trend that has been noted in the more recent literature on diaspora is the role that religion plays as a 


\section{PROOF}

Virinder S. Kalra et al. 179

national formation, something that is inherently oriented towards the universal and away from the particularity of nationalism. In a sense religion resolves the inherent tension that is always present in the invocation of an $\mathrm{X}-\mathrm{Y}$ formulation when $\mathrm{X}$ and $\mathrm{Y}$ are nation states in their own right, as the question of loyalty to one or other nation is always demanded. Religion therefore provides an identity formulation which can sit within the locality without an inherent tension as it is always self-referring as universal. In that sense the emergence of British-Sikhs, American-Muslims and Caribbean-Hindus should not be seen in any sense as a return to a more essential religious South Asian form of identity formation but rather as a response to the demands from the minorities of various liberal states. This question has been addressed in the literature in a number of ways. From a functionalist perspective, religion is a useful resource for tackling complex and challenging situations. Religion is also available to be translated into the new context. Whereas the often parochial and idiosyncratic culture of the migrant cannot be understood, the very universality of religion enables it to be valued. In an early classical study of differences amongst migrant generations, Herberg mates the salient point: 'What the son wishes to forget the grandson wishes to remember. But what he can remember is obviously not his grandfather's foreign culture; it is rather his grandfather's religion' (Herberg 1955: 64). For the Punjabi in Lahore, the religion of the grandfather is present in the everyday, but the streets and lanes of Amritsar are absent. But there is also a common religious practice that is absent, that of the shared celebrations of Diwali and Eid. Yet for both the Amritsari and Lahori, religion has become a much more significant form of identification than it was pre-partition. The process of immigration itself can be argued to be a 'theologizing experience' (Duderija 2007: 143). Especially in a context where the materiality and lived reality of multi-religious living is lost, the coalescing of identities around a particularly literalist or scripturalist form provides a rationale for the presence of a hard border.

This religiosity plays out at the level of economic transfers also. The metropolitan diaspora provides remittances to the establishment and embellishment of religious institutions. The re-guilding with gold leaf of the dome of the Harimandir in Amritsar at an estimated cost of Rs 90 crore was managed and largely paid for through donations from the metropolitan diaspora. The renovation of Guru Ram Das's birthplace, Gurdwara in Chuna Mandi Lahore, is being carried out by a Sant from Tarn Taran, East Punjab, with donations from Sikhs in India and the metropolitan diaspora. Similarly the main shrines at Qadiyan of 


\section{Diasporic Shrines in South Asia}

the Ahmediyyas are maintained by the group in Lahore with financial support from other diasporic spaces. The literature on diaspora and development, however, remains largely focused on remittances from the metropole to the South. These claims can be summarized in the statement that migration and the resultant remittances those migrants send 'back home' (i.e. the flows of money, knowledge and universal ideas) can have a positive effect on what is called 'development'. There is another element to the role that metropolitan diasporas are called on to perform which is of relevance to the Indo-Pak context. In conflict situations a diasporic group can serve as interlocutors - the premise being that residence in the West will have inculcated some of the values that are being promoted through development discourse. For example, the United States called upon the skill set of the Afghani and Iraqi diaspora settled in the United States, after its imperialist intervention in these nation states, to be involved in post-war reconstruction (von Carlowitz 2004). This involvement rests on the premise that the diaspora is in agreement with the intervention in the first place or even the nature of liberal democratic social formations that underpins much development practice. In reality of course diasporic groups even in post-conflict settings are much more interested in channelling money to family or local community concerns rather than in line with broader developmental aims (Van Hear 2011). Where donations or skill transfer takes place to larger concerns, this is often for the building of a school or health centre, for the improvement of a house or for reconstruction in the wake of a disaster (Kalra and Rehman 2006). What is of further significance about diasporic giving is the informal, often haphazard and non-state nature of the donations (Dusenbery and Tatla 2010). It is this chaotic element which is in fact its greatest strength as it is able to circumvent the restrictions that conflicting nation states may place on these movements. When this is combined with the special place that religious shrines have in South Asia, quite unusual occurrences can take place. A recent example is illustrative of the way in which individual giving to a shrine can work even at the highest level of politics. On the 8th of April 2012, Asif Ali Zardari, President of Pakistan, paid a private visit to Ajmer Sharif in Rajasthan. This was an entirely private visit though it was facilitated by the Indian state in terms of security. On the visit Zardari announced a donation of one million dollars for the shrine as an entirely personal gesture. Given that the tension between India and Pakistan has remained relatively high since the Mumbai attacks of 2008 , the fact that a visit of this kind and a donation of this size can be 


\section{PROOF}

Virinder S. Kalra et al. 181

made demonstrates the way in which religious institutions in particular contexts are able to overcome entrenched political positions.

It is perhaps ironic that shrines are a site of such reconciliation when religion was mobilized in the violence and boundary making that frames partition. The ambivalent role that religion can play in social matters is also present in much contemporary development discourse. On the one hand, there is a recognition that faith-based organizations (FBO) provide material benefit in those places where the state does not function well or at all. At a broader level religious conviction is often the motivation behind those engaged in charitable activities (Jawad 2009). Though at the formal level, development discourse is more inclined to those aspects of FBO activities that coincide with secular aims and programmes. On the other hand, there are almost always certain points where secular modernist development discourse clashes with religious traditions; this is most notably when it comes to women and sexual rights. Restrictions on women's mobility and persecution of LBGT (Lesbian, bisexual, gay and transgender) groups are often justified in the name of religious traditions. It is in the arena of personal ethics and morals that religion and development discourse are most likely to clash (Hope and Timmel 2003, Swami 2003). There are positive examples of what might be called faith-based diplomacy having a positive impact on a conflict situation, the civil war in Mozambique being one of the most notable examples. Yet in the Rwandan genocide the Catholic Church was deeply implicated in the colonial differences created between Hutus and Tutsis (Hayne 007). What is perhaps most clear from these examples is the potential that religion contains, to intervene in the provision of social welfare, to act as a motivation for those willing to engage in social work and as a mediator in situations of conflict. It is not, however, outside of any particular context possible to ascertain whether religious ideology or institutions will have a positive or negative impact on any given situation. There is nothing inherent about religion as an ethical and moral system (alongside humanism, socialism, etc.) that will necessitate a more humane outcome.

\section{Sufi shrines and welfare}

Shrines form a ubiquitous parallel universe of piety in rural and urban Punjab, far outnumbering the formal institutions of Mosque, Mandir or Gurdwara. Every village has some form of shrine that in the West Punjab takes the hue of a Sufi saint, known or unknown, living or deceased, but 


\section{PROOF}

always with some associated miracle or achievement. In East Punjab, the shrines to Gugga Pir and Sitla Devi sit alongside innumerable do-it-yourself sites of worship, large and small. In pre-partition Punjab formal religious identity rarely interfered with popular spiritual practices involving shrines, whether of Sufis or of local deities. These practices were associated with local textual sources, most famously Heer Ranjha (Mir 2010) but also Gugga Bani (Bhatti 2000) and various other texts associated with a particular spiritual figure. As these shrines grew larger they attracted more and more followers with the culmination of an annual cycle of events being a mela. For the Sufi saints this would be marked in terms of a death anniversary but for others it might mark a birth or a particular event.

The institutionalization of the shrine in Punjab is perhaps best examined through the Sufi case, though the process is also the same for Bhakti saints and the Sikh Gurus. As wandering Sufis from the West came to Punjab, they settled and found followers. Centres were established around the graves of these early itinerants (famously such as Data Sahib in Lahore in the eleventh century) by their spiritual successors and their followers. These sites served not only a spiritual function but also a practical one, forming what were known as Khankas or abodes for wandering spiritual figures or for those who were also followers but lived at a distance from the shrine. Regardless of religious affiliation, the establishment of what might generically be called deras shared some common features. Firstly, they would welcome any traveller, regardless of particular religious affiliation as long as they paid respect to the particular religious figure to whom the shrine was devoted to. Secondly, travellers would find food at these places and this would again be part of a communal kitchen run by followers of the spiritual figure. Some of these institutions, as they grew larger, would appoint khalifas or deputies who would go to nearby towns and villages, and sometimes further afield, and establish links with the central shrine, providing continuities for those who lived at too much of a distance to visit often.

Though little is known about how these shrines were embedded within the Moghul Empire, Gilmartin (1988) hypothesizes, on the basis of their role in the British Empire, that they formed part of a network linking the local with the imperial centre. By providing patronage to the Sufi Pirs, often the ancestors of the original saint, shrines ended up owning land sometimes running into the thousands of acres. The income from this land would maintain the shrine and pay for the food and activities of the Pir. However, this also meant that the Pir and their families would often be wealthy. This material and spiritual power was a 


\section{PROOF}

Virinder S. Kalra et al. 183

potent force in rural Punjab and one that was recognized by the British. They maintained a disdain for shrine-based religion, seeing it as a hindrance to rural uplift and a superstitious decay of true Islam (Thorburn 1874). However, soon, the practical necessities of governance in rural areas meant that they continued with much of the patronage practices of the Mughals. The initial distaste transferred into a policy of collaboration and distance transferred into a policy of providing and preserving lands to an already strong Pir (Talbot 1998).

With the formation of Pakistan, the role of the landed Pirs was maintained and they have come to prominence in the political sphere (see Ansari 1992). A most recent example of this is the Prime Minister of Pakistan Yusaf Gilani who comes from a long line of Pirs from Multan who were part of the British colonial establishment, having legislative assembly seats from the beginning of local governance in Punjab. Nonetheless, like many other postcolonial states, the effectiveness of the Pakistani state in delivering social and health services was limited by a range of factors and the space opened up by the absent state was taken up by a number of actors. Most notably, Islamic political parties began to enhance and develop their social and welfare role, explicitly, in the absence of being able themselves to achieve state power. The is perhaps the most notable in this regard, but by no means the only group to act in this way Jamaat-i-Islami. Indeed as part of its political outlook tackling social inequality is seen as a duty for Muslims. The Jamaat runs various welfare organizations that are ostensibly independent but are all linked back to the central party. The most prominent of these is the Al-Khidmat Foundation, but there are also specific organizations in specific fields, for example the Al-Ghazali, Al-Arkam and Al-Hira Trust which operate schools and fund scholarship programmes (Deneulin 2009). This extensive welfare work has not translated into general political collateral for the Jamaat but has given them considerable credibility, especially when it comes to disaster relief. All of this development work is seen as an aspect of doing God's work rather than worthwhile within itself, which is the main distinction between secular and religious development (Jawad 2009).

Partly the nature of the Pakistani state means that even though it is constitutionally a religious state, in practice there is a great deal of separation of the state from religious affairs. Even though zakat is the wealth tax within Islam, in Pakistan it is viewed much more as a donation to charitable and good causes. Income tax, property tax, sales tax and so on are charged separately and are seen necessary for the running of the state. Zakat collection and distribution is therefore much more ad hoc 


\section{PROOF}

and utilized for short-term immediate relief rather than for long-term or infrastructural development. A similar situation exists for the gifts of land or Waqf (Endowments), whereby property or money is given to a shrine or to a Pir. This again is for non-commercial use for the good of the 'community'. But Waqf is subject to a wide range of uses and abuses and is deeply entwined with market and state practices, while maintaining an ostensibly charitable purpose (Malik 1996). The involvement of the state in a direct manner in shrine management has reduced the agency and increased their bureaucratization, yet the large Sufi shrines of South Asia still play a significant role in providing welfare in their localities as is demonstrated by the case of Mian Mir in Lahore.

\section{Mian Mir}

The shrine of Mian Mir is ostensibly built up around the place of the tomb of the spiritual figure Mian Mir who lived from 1550-1635, having moved to Lahore in 1575 where he spent the rest of his life until his death. While there is much to be said about the shrine as a sacred space in terms of the ways in which it is venerated, there is also much to be said about how it functions as a space of sociality. By reflecting upon fieldwork that was carried out in 2008-2010, and briefly in 2012, some aspects of the social life of the shrine ties together a number of different themes about the shrine's significance in worshippers' lives; in particular, the role that the shrine plays in providing welfare of a material and spiritual variety. Indeed, the distinction between material and spiritual well-being is fundamentally questioned by the uses of the shrine and links closely into the debates about the role of religion and development. Beyond the individual accounts of the shrines' function, the formal management of the shrine also explicitly engages in providing health and education facilities, though it remained slow and in need of improvement. These are tied into the state through the Auqaf department but remain outside of the formal state provision of the health and education departments. Finally, the structure of the shrines' management, as with most large religious institutions, is contested. It is through this contestation that a transnational space emerges in which the Punjabi diaspora of various religious affiliations is able to engage with the shrine outside of the political disputes of the Indian and Pakistani state.

The current shrine at Mian Mir is located in the working-class part of Mian Mir Cantonment, which is otherwise also home to some of Lahore's more wealthy residents. This area was developed by the British 


\section{PROOF}

Virinder S. Kalra et al. 185

Indian Army, allegedly on the Waqf (Endowed) land of Mian Mir shrine, and still carries the appellation Cantonment. The shrine itself is a large complex with an inner courtyard, the central focus of which is the housing of the tomb and a mosque to one side with its own large prayer hall. Worshippers (zaireen) offer prayers at the shrine and engage in a range of rituals. They also provide income to the shrine through donations. Though it is fairly difficult to ascertain the income of the shrine as the Auqaf department is rather opaque when it comes to financial matters, the manager of the shrine did provide some details of the number of employees and the budget from two periods of time from 1995 to 1996 and 2008 to 2009. In both of these cases the income of the shrine was less than the overall expenditure, but perhaps more significantly the income had risen from about Rs 2.2 million to Rs 6.75 million annually over that period of time, which reflects the extent to which the shrine attracts followers and those willing to contribute to its running and upkeep.

It is this funding that enables a range of social welfare activities to take place. The following are the social services one can find at the shrine of Mian Mir: Dastakari (embroidery) School; Library; Dispensary, Hospital of 130 beds (under Construction), Water Cooler (outside the shrine). Each of these provides facilities to the local population and on the occasion of the annual death anniversary (Urs) to a wider population also. The social life of the shrine revolves around the week in which Thursday attracts the most worshippers, with the weekend being busy also. Thursday is the day that individuals come to pray, to offer food for other worshippers, socialize, meet the Pir and in the evening to listen to Qawaali. Indeed, food is one of the main ways in which the shrine acts as a source of welfare for the poor. There is a large Langar (free food) Hall recently constructed adjacent to the outer wall of the shrine, though within the Waqf land of the shrine. The need for a Langar Hall was reflected through the need for catering to the tens of thousands of visitors that are attracted to the shrine at the time of the Urs/death anniversary of the Saint. ${ }^{3}$ In addition to the shrine providing and more often facilitating the provision of food, there are also health facilities.

The shrine has a medical dispensary within its own premises situated in a small room, at the end of the Eastern part of the shrine. The dispensary is an extension of the Data Darbar hospital, which is attached to the shrine of Data Sahib, also in Lahore and perhaps the shrine with the most income in the whole of Pakistan. It is managed by the hospital's medical staff whenever needed. Most of the time medicines come from Data Darbar hospital and are provided freely to the patients. The 
dispensary was initiated in the 1970s and provides basic medicines on a daily basis to worshippers. It is a first point of call for the worshippers as it also carries the potential of healing associated with the saint. Indeed, the facilities at the dispensary are basic and anything complicated is referred to the Data Darbar hospital, but the importance of the spiritual connection to healing and health is crucial. Many of the hagiographical tales from Mian Mir's life illustrate the healing power of the saint:

One day a man in a very restless mood came to Mian Mir and told that saint of his sick child. The man told of how his child was becoming worse and worse and that his only hope rested in the Saint giving blessing and returning his son to health. After hearing the sad story, Mian Mir become very restless and after a while he asked to bring a pot of water and asked that man to take this water home and give this to his son to drink. After drinking the water suddenly the boy started feeling well.

Another man took his son to Mian Mir and told him: My son is now 7 years old and he still can't speak a single word. Mian Mir prayed for the boy and then said to the boy to read 'Bismillah' which the boy read out loud. With the blessings of Mian Mir the boy became a Hafiz-e-Quran (one who can recite the Quran by rote). (p. 179)

Hazrat Mian Mir said once upon a time a Pathan came to visit me and he was very upset and requested me to pray for him. Seeing his distress I prayed for him and advised him to feed the hungry people and give clothes to the needy. I told him: If you do this I guarantee you that your wishes will be fulfilled by the virtue of these good virtues. After hearing this advice the Pathan set off for this home on his return journey he saw a hungry man. The Pathan gave him his ring so that he could buy food. After a little more distance, the Pathan saw some people with barely enough clothes to cover their bodies. The Pathan provided them clothing. When he was about to reach home, he met a neighbor and expected bad news. But the neighbor said that the Pathan's relative had made a miracle recovery. The Pathan came back to me with some money and Halwa (pudding). I asked the reason of all these things. He said due to your prayer my family member who was ill has become healthy. I distributed the Halwa among the mendicants (Darvesh) and returned the money to him. (p. 183)

These stories are then reflected in the personal narratives that were told to us in interviews: 


\section{PROOF}

Virinder S. Kalra et al. 187

(Mr. Fazal narrates his story): Once I was suffering from ear pain. It was so severe that it was shattering my mind. My grand father brought me to the shrine of Mian Mir. He putted a little bit of dust from the floor of the shrine into my ears and recited some words. Suddenly I felt my pain vanish and I was relieved.

(Interview was conducted with an old lady): My daughter was ill. I went to a doctor and they said it is cancer but another man said it is just like a Zahir Bad (big pimple). I felt relief about my daughter's trouble after praying at Mian Mir shrine. Another lady told me that the same case happened with her. We prayed at Mian Mir shrine and now the problem is ok. I have been coming to Mian Mir shrine for the last 25 years .... Some years ago ago it was a jungle and only a few people came here. But now a lot of people come, they all have some troubles to share, a lot of women come. Women come here because they know about the real problems they face in the household, more than men. So they came here to pray.

The role of the shrine in providing psychological as well as material support cannot be fully appreciated and to some extent pushes thinking about development activities into the direction of well-being in a totalizing sense. The state, the spiritual power and authority of the saint and the material and welfare needs of the community all meet in the shrine. The medical dispensary is a clear case of the funds from the shrine being used for philanthropic purposes; however, the location and accessibility of the shrine means that welfare activities which involve other charitable organizations as well as other departments of the state are also homed there. While small-scale activities remain within the management of the shrine, larger projects have to involve departments of the government and can therefore get embroiled in local politics and the changing machinations of the state. A good example of this is the hospital, which is not within the boundary wall of the shrine but is on the Waqf land allocated to the shrine. The hospital got its inception due to the efforts of the local member of the Punjab Assembly (MPA). The locals of the area pressured him to build a hospital as there was a large tract of land lying vacant around shrine. With the efforts of the MPA, a pact between District Government and Auqaf department took place according to which the Auqaf department would provide land on lease basis for 33 years. The District Government would spend all the rest of the money to construct and run the hospital. The idea materialized after three years of efforts in 2005. The construction however took 
further delays and the construction got started at the end of 2006. The construction was to end in 2009, however, the hospital project took far more time than anticipated and it still seems will only be completed by 2014. This involvement of the local state with the shrine resulted in the same kind of bureaucratic difficulties and political delays that behest the rest of the state. The involvement of NGOs has on the other hand been more successful.

The social space of the shrine operates outside of the norms that determine women's patterns of mobility and practice. At Mian Mir there is no forced gender segregation and it is only the inner sanctum of the shrine that is deemed off limits. ${ }^{4}$ Indeed, women are allowed much greater freedom in the shrine than would be imagined on the street outside (Purewal and Kalra 2010). The fact that women are allowed to come to the shrine and it is often a refuge for working class and outcaste women has meant that NGOs have seen this as a site to carry out certain types of activities. At Mian Mir there is a vocational Dastkari (embroidery) school for women, which is adjacent to the dispensary. It is run by the Upper Mall Scheme Society with the permission of the Auqaf department and was established in 1970. A retired Brigadier is the head of the society and generates funds for running the school. Students are not charged a fee and the school offers short courses of 3-6 months in a range of vocational pursuits. This combination of the Auqaf with an outside organization is also present in the running of the Library which is present inside the complex. Though the library is formally run by the shrine's manager and comes under the control of the Religious committee, which is appointed to oversee the activities of the shrine, it also has the involvement of another trust, based in Faisalabad (about 100 miles distant from Lahore). Sufi Barkat Ali Ludhianvi was a devotee of Mian Mir and used to come to the shrine every day for many years spending most of his time in the library. After his death special permission was given for running the library and keeping books written by Sufi Barkat Ali to the trust developed at Sufi Barkat Ali's shrine. This kind of partnership has enabled the Mian Mir shrine to enhance and develop its activities.

\section{Transnational ties}

One of the main tensions in the organization of the shrine is between the hereditary Pirs (or gaddi nashins - literally, those sitting on the seat) and the Auqaf department. Even though Mian Mir himself did not have any children, his close followers took over the management and 


\section{PROOF}

Virinder S. Kalra et al. 189

running of the shrine, and it is those families that were managing the shrine before the formation of Pakistan. The state, through the Auqaf department, took over the formal management of the major Sufi shrines in the 1960s (Malik 1990) with the result that hereditary Pirs were sidelined. In the case of Mian Mir this has meant that the gaddi nashin or his sons come to the shrine on Thursdays where they are greeted by those worshippers who have long standing relations with the family. By and large, they are peripheral to the main activities at the shrine which are funded and managed by the state. The family has however set up their own shrine in their family house on Walton Road in Lahore where they claim to have artifacts of Mian Mir and of the Sikh Gurus who were said to be his friends. The family also set up a charitable trust in the name of Mian Mir (mianmir.org), headed by Chan Pir (formally known as Makhdom Syed Chan Pir Al-Gillani Al-Qadri). The fact that the Auqaf department is part of the government necessarily restricts its activities when it comes to Sikh and Hindu pilgrims from India (and the metropolitan diaspora), whereas the Mian Mir trust can act with relative freedom as an independent body.

At the time of the visitations of Sikhs on the occasions of Guru Nanak's birthday and Vaisakhi, Mian Mir is one site that those staying at the Dera Sahib Gurdwara in Lahore come to visit. According to the manager of Mian Mir, in 2011 about 300 Sikhs came in formal groups to visit the shrine. On these occasions, the local police provide security and the Langar Khana (food hall) which is usually only opened at the time of the Urs is made available. These formal occasions are part of the general management of pilgrimage that is organized by the Indian and Pakistani states. However, due to the international network that the Mian Mir Trust has managed to develop and in particular the presence of the trust in East Punjab, they also facilitate visits for those who wish to visit the shrine and Lahore more generally. This network encompasses those nodes of the Punjabi diaspora which include Muslims, Sikhs and Hindus. Manchester, Kuala Lumpur, Singapore, Amritsar and Lahore are the places that encompass the diasporic space of Mian Mir. Whereas the Auqaf board can control access to the actual shrine and also provide services to large groups of pilgrims, small scale people-to-people contact is facilitated by organizations like the Mian Mir Trust. By utilizing the legitimacy of the religious shrine they are able to circumvent the bureaucratic and often purposefully obtuse machinations of the Indian and Pakistani state.

Indeed, the representative of the Trust in India, Harcharan Singh Brar, sees himself as part of a process of facilitation for people who want to 


\section{PROOF}

go to Lahore or come from Pakistan to India. This process began only after he visited Pakistan as part of an official delegation and came across the gaddi nashin of Mian Mir. This is therefore a two-way process, as Brar also hosts those who visit from Pakistan, liaising with the Indian authorities to enable the granting of visas. Though religious persons and those closely allied to a particular shrine are able to apply for pilgrimage on various routes that traverse South Asia, most notably to visit the main Chisti tombs, Ajmer in Rajashtan (India) and Baba Farid in Pak Pattan (Pakistan), there are often restrictions when it comes to Punjab due to its strategic location as a border region. What is significant about the work of the Mian Mir Trust is the way that it facilitates ordinary worshippers who have historic links to the shrine to visit. This interview was carried out with two visitors from East Punjab at the shrine in 2009:

My name is Surjit Singh and my friend is Harish Jain ... we are from Gurdaspur.... Our elders told us that they would come to Mian Mir every year before partition... We always wanted to visit but you know that the Akalis [Sikh political party] reserve so many of the places on the pilgrim visits that it is too hard to get on ...then we found out about the Mian Mir Trust in Amritsar and we got in touch and they helped us to come here... we are so happy to finally visit where our ancestors once came...

It would be naïve to assume that these organizations and their engagements escape the attention of the Indian and Pakistani states or other forms of controversy. ${ }^{5}$ Nonetheless, by tapping into diasporic social networks they do provide an alternative route for people-topeople contact in a zone of conflict. Perhaps what is even more notable, particularly in the example of the shrine of Mian Mir, are the ways in which 'development' and welfare activities are provided, delivered and availed of within a context of religious congregation. The shrine of Mian Mir in Pakistan highlights the continuing significance that the spiritual and social dimensions shrines have in contemporary South Asia, which goes beyond servicing the mere locality but also drawing upon networks in order to transcend the immediate national and religious boundaries.

\section{Conclusion}

The benefits of diaspora for development have been mainly couched in terms of the ways in which settled groups in metropolitan locations can aid their homelands at a political, social and economic level. This 
perspective also tied in with the role that religion is seen to play in the discourse of development, an ideology that is close to the people who are subject to policy and can give legitimacy to initiatives. However, in both of these endeavours, what underpins this is a certain utilitarian attitude towards diasporas and the role of religion, indeed this is what can be seen as a link. The haphazard nature of diaspora giving is not therefore deemed compatible with organized state to state planning, but potentially fits in with a more neo-liberal NGO led discourse. Similarly, religious giving and the role of religious groups in implementing formal development goals have come to be recognized, but with the caveat that there are certain issues such as gender and sexuality which can be sources of tension.

In this chapter this literature has been stretched by evoking the idea of the diaspora across the Indo-Pak border. Rather than the metropolis being the central node in the transnational circulation, peripheries as sites of desire come to the fore. Here we need to pay account to the way in which Ludhiana and Faislabad, Lahore and Amritsar, Karachi and Mumbai create desiring populations who in multiple ways recreate (both negatively and positively) images drawn from memory and crystallized by forced and enforced separation. One method by which the border is circumvented is through the relatively easy movement of pilgrims to shrines. This is organized by the state and managed through various intermediary bodies. However, the legitimacy on people-to-people contact that is enabled through pilgrimage opens up a space in which organizations such as the Mian Mir Trust can arrange for individuals and groups to travel and meet. Though this kind of contact may not yield immediate political change and results it does demonstrate the role that religious institutions can play in ameliorating conflict.

\section{Notes}

1. Though of course small populations of both communities remained, Sikhs in Lahore/ Nanakana Sahib and a more substantial population of Muslims in Malerkotla.

2. Though of course there are specific institutional factors that prohibit Palestinians from holding citizenship in these neighbouring countries that do not exist in the South Asia case.

3. Indeed, the growth of the Mian Mir complex could be illustrative of the robust nature of shrine based Islam in the face of more literalist approaches, though it could also be reflective of the burgeoning Pakistani population.

4. This was also seen as a development that came after the 1980s Zia period.

5. In 2005, Brar was accused of embezzling funds from would be travellers and the Mian Mir Trust in Pakistan distanced itself from the Amritsar group. 


\section{References}

Ansari, Sarah (1992) Sufi Saints and State Power: The Pirs of Sind, 1843-1947, Cambridge: Cambridge University Press.

Bhatti, Harvinder (2000) Folk Religion; Change and Continuity, New Delhi: Ravat.

Brah, Avtar (1996) Cartographies of Diaspora: Contesting Identities, London: Routledge.

Deneulin, Severine, with Masooda Bano (2009) Religion in Development: Rewriting the Secular Script, London: Zed Books.

Duderija, Adis (2007) Literature Review on Identity Construction in the Context of Being a Minority Immigrant Religion: The Case of Western Muslims. Journal of Minorities and Immigrants, 25:141-162.

Dusenbery, Verne and Tatla, Darshan S. (eds) (2010), Sikh Diaspora Philanthropy in Punjab: Global Giving for Local Good, New Delhi: Oxford University Press.

Gilmartin, David (1988) Empire and Islam: Punjab and the Making of Pakistan, Berkeley: University of California Press.

Hall, Stuart (1992) 'The West and the Rest: Discourse and Power', in Stuart Hall and Bram Gieben, eds. Formations of Modernity, Milton Keynes: Open University, 275-331.

Herberg, William (1955) Protestant, Catholic, Jew. An essay in American Religious Sociology, New York: Doubleday.

Hope, Anne and Timmel, Sally (2003) 'A Kenyan Experience for Faith-Based' in Thomas Faist, Margit Fauser and Peter Kivisto, eds. The Migration-Development Nexus. A Transnational Perspective, London: Palgrave, pp. 85-104.

Jawad, Rana (2009) Social Welfare and Religion in the Middle East: A Lebanese Perspective, Bristol: Policy Press.

Kalra, V and Purewal, N (1999) 'The Strut of the Peacock: Travel, Partition and the Indo-Pakistan Border' in John Hutnyk and Raminder Kaur (eds.) Travel Worlds: Journeys in Contemporary Cultural Politics, London: Zed Books.

Kalra, V. and Purewal, N. (2010) 'Women's Popular Practices as Critique: Vernacular Religion in Indian and Pakistani Punjab,' Women's Studies International Forum, 33: 383-389.

Kalra, V and Rehman, S. (2006) 'Transnationalism from Below: Initial Responses by British Kashmiris to the South Asia Earthquake of 2005' Journal of Contemporary South Asia, 15: 309-323.

Kaur, Ravinder (2007) Since 1947: Partition Narratives among Punjabi Migrants of Delhi, New Delhi: Oxford University Press.

Malik, Jamal (1990) 'Waqf in Pakistan: Change in Traditional Institutions', Die Welt des Islams, New Series, 30: 63-97.

Malik, Jamal (1996) Colonization of Islam: Dissolution of Traditional Institutions in Pakistan, Delhi: Manohar.

Mir, Farina (2010), The Social Space of Language: Vernacular Culture in British Colonial Punjab, Berkeley: University of California Press.

Oldenburg, Philip (2010) India, Pakistan and Democracy: Solving the Puzzle of Divergent Paths, London: Routledge.

Purewal, Navtej (2006) Borderland Punjab, Seminar, http://www.india-seminar. com/.

Swami, Agnivesh (2003) 'A Spiritual Vision for the Dialogue for Religions', Development, 46 (4):35-8. 


\section{PROOF}

Virinder S. Kalra et al. 193

Talbot, Ian (1998) Pakistan: A Modern History, London: Palgrave.

Talbot, Ian (2000) Inventing the Nation: India \& Pakistan, London: Palgrave Macmillan

Thorburn, S.S. (1874) Musalmans and Money Lenders in the Punjab, Lahore: Book Traders.

Van Hear, Nicholas (2011) 'Diasporas, Recovery and Development in Conflictridden Societies: Transformative Action,' Development, 46:93-99.

Von Carlowitz, Linden. (2004) 'Migranten als Garanten? Über die Schwierigkeiten beim Rechtsstaatsexport in Nachkriegsgesellschaften,' HSFK Standpunkte 6, Frankfurt am Main: Hessische Stiftung für Friedens- und Konfliktforschung. 